\title{
Faktor-Faktor yang Mempengaruhi Produksi Usahatani Kacang Hijau di Desa Tunabesi Kecamatan Io Kufeu Kabupaten Malaka
}

Esterlina Moy ${ }^{\mathrm{a}}$, Yosefina Marice Fallo ${ }^{\mathrm{b}}$, dan Marsianus Falo ${ }^{\mathrm{c}}$

${ }^{a}$ Fakultas Pertanian, Universitas Timor, Kefamenanu, TTU - NTT, Indonesia.

${ }^{b}$ Fakultas Pertanian, Universitas Timor, Kefamenanu, TTU - NTT, Indonesia.

${ }^{c}$ Fakultas Pertanian, Universitas Timor, Kefamenanu, TTU - NTT, Indonesia.

\section{Article Info}

\section{Article history:}

Received 21 September 2017

Received in revised form 9 Oktober 2017

\section{Keywords:}

Faktor Produksi

Usahatani

Jagung

Tunabesi
Accepted 13 Oktober 2017

\begin{abstract}
Abstrak
Io kufeu adalah salah satu kecamatan di kabupaten Malaka yang sebagian besar masyarakatnya melakukan usahatani kacang hijau. Salah satu faktor yang menentukan keuntungan ekonomis suatu usahatani adalah jumlah produksi usahatani tersebut, sementara produksi itu sendiri dipengaruhi oleh berbagai faktor. Faktor-faktor yang mempengaruhi produksi sebuah usahatani sangat penting untuk diteliti agar diketahui bagaimana kontribusi setiap faktor terhadap produksi usahatani tersebut, sekaligus menjadi dasar bagi petani agar menjaga efisiensi pemanfaatan dari setiap faktor produksi serta sebagai input pengambilan keputusan dalam pengembangan usahatani. Tujuan penelitian ini adalah untuk mengetahui faktor-faktor yang mempengaruhi produksi kacang hijau di desa Tunabesi, kecamatan Io kufeu, kabupaten Malaka. Penelitian dilaksanakan di desa Tunabesi, Kecamatan Io Kufeu, kabupaten Malaka, pada Bulan Februari sampai Juni 2016. Populasi berjumlah 554 orang dengan sampel sebanyak 51 orang. Data yang diperoleh dikumpulkan kemudian ditabulasi dan dianalisis menggunakan analisis regresi linear berganda. Hasil penelitian menunjukkan bahwa sebesar 82,3\% produksi usahatani kacang hijau dipengaruhi oleh luas lahan, benih, curahan tenaga kerja, tingkat pendidikan, dan pengalaman secara bersama-sama sedangkan sisanya $17,7 \%$ adalah variabel lain. Secara parsial hanya variabel benih dan pengalaman petani yang berpengaruh terhadap produksi kacang hijau sedangkan luas lahan, curahan tenaga kerja dan tingkat pendidikan tidak berpengaruh nyata terhadap produksi usahatani kacang hijau. (0)2017 dipublikasikan oleh Agrimor.
\end{abstract}

\section{Pendahuluan}

Kacang hijau adalah salah satu komoditas tanaman kacang-kacangan yang banyak dikonsumsi oleh masyarakat Indonesia dalam bentuk seperti bubur kacang hijau, isi onde-onde dan lain-lain. Kecambahnya dikenal sebagai tauge (sayuran). Tanaman ini mengandung zat-zat gizi, antara lain amylum, protein, besi, belerang, kalsium, minyak lemak, mangan, magnesium, niasin, vitamin (B1, A, dan E). Kandungan gizi kacang hijau per 100 gr bahan adalah Kalori (kal) $323 \mathrm{kal}$, Protein 22 g, Lemak 1,5 g, Karbohidrat 56,8 g, Kalsium 223 mg, Zat Besi7,5 mg, Fosfor $319 \mathrm{mg}$, Vitamin A 157 SI, Vitamin BI 0,46 mg, Vitamin CI $10 \mathrm{mg}$ dan Air 15,5 g (Rukmana, 1997).

Io kufeu adalah salah satu kecamatan di kabupaten Malaka yang sebagian besar masyarakatnya melakukan usahatani kacang hijau. Luas lahan dan produktivitas kacang hijau di wilayah Io kufeu pada tahun 2013-2015 berfluktuasi secara signifikan. Pada tahun 2013 luas lahan kacang hijau 5 ha dengan produktivitas 1,8 t/ha (BPS Kab. Malaka, 2014), selanjutnya tahun 2014 luas lahan kacang hijau meningkat menjadi 14 ha tetapi produktivitas menurun menjadi 0,58 t/ha (BPS Kab. Malaka, 2015), sebaliknya pada tahun 2015 luas lahan kacang hijau kembali meningkat menjadi 100 ha dengan produktivitas yang juga meningkat dari tahun sebelumnya menjadi 0,9 t/ha (BPS Kab. Malaka, 2016). Produktivitas ini masih rendah jika dibandingkan dengan produktivitas kacang hijau yang dihasilkan pada beberapa penelitian terdahulu di wilayah kabupaten Timor Tengah Utara yakni 1,02 t/ha (Neonbeni \& Seran, 2017) bahkan mencapai 1,9 t/ha (Manehat et al., 2016).

Desa Tunabesi merupakan salah satu desa yang dalam wilayah pemerintahan termasuk dalam wilayah pemerintahan kecamatan Io kufeu, kabupaten Malaka Sumber pendapatan masyarakat desa Tunabesi sebagian besar diperoleh dari bercocok tanam. Banyak komoditi yang dibudidayakan oleh masyarakat desa Tunabesi, namun berdasarkan data dalam observasi awal ternyata kebanyakan masyarakat desa Tunabesi memilih komoditi kacang hijau sebagai komoditi unggulan desa itu. Produksi kacang hijau di desa Tunabesi sangat menjanjikan, namun masalah yang dihadapi oleh para petani adalah lahan yang begitu luas tapi produksi kacang hijau tidak mencapai apa yang diharapkan oleh petani. Selayaknya usahatani lain, usaha tani kacang hijau kacang hijau sudah lama dijalankan dan dikembangkan oleh masyarakat ini diyakini memberikan manfaat secara nyata terhadap perekonomian petani. Tetik \& Fallo, (2016) memberi gambaran bahwa usahatani kacang hijau di kecamatan Wewiku kabupaten Malaka ekonomis menguntungkan sehingga usahatani tersebut mempunyai prospek yang lebih baik untuk terus dikembangkan.

Salah satu faktor yang menentukan keuntungan ekonomis suatu usahatani adalah jumlah produksi usahatani tersebut, sementara produksi itu sendiri dipengaruhi oleh berbagai faktor. Faktor-faktor yang mempengaruhi produksi sebuah usahatani sangat penting untuk diteliti agar diketahui bagaimana kontribusi setiap faktor terhadap produksi usahatani tersebut, sekaligus menjadi dasar bagi petani agar menjaga efisiensi pemanfaatan dari setiap faktor produksi serta sebagai input pengambilan keputusan dalam pengembangan usahatani. Falo et al., (2016) menyatakan bahwa dalam penentuan strategi pengembangan usahatani tentunya petani dituntut untuk memperhatikan faktor eksternal dan internal yang terkait. Oleh karena itu, perlu dilakukan kajian dengan topik "Faktor-Faktor yang Mempengaruhi Produksi Usahatani Kacang Hijau di Desa Tunabesi Kecamatan Io kufeu Kabupaten Malaka" dengan tujuan untuk mengetahui faktor-faktor yang mempengaruhi produksi kacang hijau di Desa Tunabesi.

\section{Metode}

Penelitian dilaksanakan di desa Tunabesi, Kecamatan Io Kufeu, kabupaten Malaka, pada Bulan Februari sampai Juni 2016. Populasi dalam penelitian ini adalah semua petani kacang hijau di desa Tunabesi yang berjumlah 554 orang Teknik pengambilan sampel dalam penelitian ini menggunakan teknik simple random sampling yaitu pengambilan sampel secara acak dimana setiap elemen dari populasinya mempunyai peluang yang sama-sama besar untuk terpilih ke dalam sampel. Teknik pengambilan dan penetapan jumlah sampel penelitian dilakukan dengan cara menggunakan rumus slovin sesuai petunjuk Ating \& Sambas, (2006), sehingga jumlah sampel atau responden sebanyak 51 orang.

Data yang digunakan dalam penelitian ini adalah data primer yang diperoleh dengan teknik survei, observasi dan wawancara langsung dengan responden atau petani kacang hijau di lokasi penelitian berdasarkan daftar pertanyaan yang disiapkan oleh peneliti sedangkan data sekunder diperoleh dari instansi atau lembaga terkait. Data yang diperoleh dikumpulkan kemudian ditabulasi dan dianalisis berdasarkan tujuan penelitian menggunakan analisis regresi linear berganda sesuai petunjuk Kurniawan, (2016) dengan model matematisnya sebagai berikut:

$$
Y=\beta o+b_{I} X_{1}+\beta_{2} X_{2}+\beta_{3} X_{3}+\beta_{4} X_{4}+\beta_{5} X_{5}+e
$$

\section{Keterangan:}

$$
\begin{array}{ll}
\mathrm{Y} & =\text { Produksi Kacang Hijau }(\mathrm{kg}) \\
\beta_{0} & =\text { Intersep } \\
\beta_{1}-\beta_{5} & =\text { Koefisien Regresi Variabel Bebas } \\
\mathrm{X}_{1} & =\text { Luas Lahan (are) } \\
\mathrm{X}_{2} & =\text { Benih }(\mathrm{kg}) \\
\mathrm{X}_{3} & =\text { Curahan Tenaga Kerja (HKO) } \\
\mathrm{X}_{4} & =\text { Tingkat Pendidikan } \\
\mathrm{X}_{5} & =\text { Pengalaman (tahun) } \\
\dot{\varepsilon} & =\text { Variabel Pengganggu }
\end{array}
$$

Data primer yang diperoleh dari hasil wawancara dengan responden diolah dengan menggunakan bantuan software SPSS versi 16.0. sesuai petunjuk Santoso, (2008)

\section{Hasil dan Pembahasan}

3.1 Koefisien Determinasi $\left(\mathbf{R}^{2}\right)$

Koefisien determinasi dari penelitian ini dapat dilihat pada Tabel 1. Nilai koefisien determinasi sebesar 0,823 artinya $82,3 \%$ produksi usahatani kacang hijau pada petani responden dipengaruhi oleh luas lahan, benih, curahan tenaga kerja, tingkat pendidikan, dan pengalaman, sedangkan sisanya $17,7 \%$ adalah variabel lain yang tidak dimasukkan ke dalam model yang diajukan.

\begin{tabular}{ccccc}
\multicolumn{2}{l}{ Tabel 1. Koefisien Determinasi } \\
Model & $\mathrm{R}$ & $\begin{array}{c}\mathrm{R} \\
\text { Square }\end{array}$ & $\begin{array}{c}\text { Adjusted R } \\
\text { Square }\end{array}$ & $\begin{array}{c}\text { Std. Error of the } \\
\text { Estimate }\end{array}$ \\
\hline 1 & $0,907^{\mathrm{a}}$ & 0,823 & 0,803 & 15.711 \\
\hline
\end{tabular}

\subsection{Pengaruh Secara Simultan}

Uji secara simultan faktor-faktor yang mempengaruhi produksi usahatani kacang hijau di desa Tunabesi dapat dilihat pada Tabel 2. F hitung sebesar 41,842 $>$ nilai $\mathrm{F}$ tabel sebesar 2,42. Karena nilai $2,42<41,842$ maka secara bersamasama variabel luas lahan, benih, curahan tenaga kerja, tingkat pendidikan, dan pengalaman berpengaruh nyata terhadap variabel produksi kacang hijau dengan taraf kepercayaan $5 \%$ 
Tabel 2. Anova Regresi

\begin{tabular}{llrrrrr}
\hline \multicolumn{1}{c}{ Model } & $\begin{array}{l}\text { Sum of } \\
\text { Squares }\end{array}$ & Df & $\begin{array}{l}\text { Mean } \\
\text { Square }\end{array}$ & F-Hitung & Signifikan & $\begin{array}{c}\text { F-Tabel } \\
(5 \%)\end{array}$ \\
\hline Regression & 51640,503 & 5 & 10328,101 & 41,842 & $0,000^{\mathrm{a}}$ & 2,42 \\
Residual & 11107,536 & 45 & 246,834 & & & \\
\hline Total & 62748,039 & 50 & & & & \\
\hline
\end{tabular}

\subsection{Pengaruh Secara Parsial}

Hasil analisis regresi secara parsial dapat dilihat pada Tabel 3. Pada kolom coefficients diperoleh nilai koefisien/parameter regresi linear berganda (B). Persamaan regresi yang diperoleh adalah $\mathrm{Y}=-17,864+0,235+15,527-0,361$ $-0,119+1,243$.

Tabel 3. Koefisien Regresi

\begin{tabular}{|c|c|c|c|c|c|c|}
\hline \multirow[t]{2}{*}{ Model } & \multicolumn{2}{|c|}{$\begin{array}{l}\text { Unstandardized } \\
\text { Coefficients }\end{array}$} & \multirow{2}{*}{$\begin{array}{c}\text { Standardized } \\
\text { Coefficients } \\
\text { Beta }\end{array}$} & \multirow[t]{2}{*}{ t-hitung } & \multirow[t]{2}{*}{ Sig. } & \multirow{2}{*}{$\begin{array}{l}\mathrm{t} \text { tabel } \\
(5 \%)\end{array}$} \\
\hline & $\mathrm{B}$ & Std. Error & & & & \\
\hline (Constant) & $-17,864$ & 11,413 & - & $-1,565$ & 0,125 & 1,680 \\
\hline Luas Lahan & 0,235 & 0,283 & 0,167 & 0,829 & 0,411 & \\
\hline Benih & 15,527 & 5,112 & 0,618 & 3,037 & 0,004 & \\
\hline Tenaga Kerja & $-0,361$ & 0,381 & $-0,062$ & $-0,947$ & 0,349 & \\
\hline Pendidikan & $-0,119$ & 1,184 & $-0,006$ & $-0,100$ & 0,920 & \\
\hline Pengalaman & 1,243 & 0,269 & 0,304 & 4,614 & 0,000 & \\
\hline
\end{tabular}

a. Pengaruh luas lahan responden $\left(\mathrm{X}_{1}\right)$ terhadap produksi $(\mathrm{Y})$

Berdasarkan hasil analisis di ketahui T hitung $<\mathrm{T}$ tabel yaitu $(0,829<1,680)$ yang berarti terima $\mathrm{H} 0$ dan tolak $\mathrm{H} 1$ dengan demikian untuk faktor luas lahan $\left(\mathrm{X}_{1}\right)$ tidak berpengaruh nyata terhadap produksi usahatani kacang hijau (Y) pada taraf kepercayaan 5\%, sehingga walaupun memiliki nilai koefisien sebesar 0,829 tetapi penambahan luas lahan tidak akan berpengaruh secara nyata terhadap produksi kacang hijau.

b. Pengaruh benih $\left(\mathrm{X}_{2}\right)$ terhadap produksi $(\mathrm{Y})$

Benih merupakan faktor terpenting dalam suatu usahatani. Berdasarkan hasil analisis diketahui T-hitung > T-tabel yaitu $(3,037>1,680)$ yang berarti $\mathrm{H} 1$ diterima dan tolak $\mathrm{H} 0$ dengan demikian untuk faktor benih berpengaruh nyata terhadap produksi usahatani kacang hijau (Y) pada taraf kepercayaan 5\%. Petani selalu mempersiapkan benih yang digunakan untuk musim tanam berikutnya, dengan asumsi bahwa setiap penambahan benih sebanyak $1 \mathrm{~kg}$ maka akan meningkatkan produksi sebesar $15,527 \mathrm{~kg}$ dan variabel lain dianggap tetap.

c. Pengaruh curahan tenaga kerja $\left(\mathrm{X}_{3}\right)$ terhadap produksi kacang hijau $(\mathrm{Y})$

Berdasarkan analisis data, diketahui T-hitung $<$ T-tabel $(-0,947<1,680)$ dengan demikian HO diterima dan H1 ditolak. Berdasarkan hasil uji statistik ini dapat disimpulkan, bahwa tenaga kerja secara parsial tidak berpengaruh nyata terhadap hasil produksi kacang hijau. Hal ini disebabkan karena tenaga kerja yang digunakan bekerja belum mengerahkan seluruh kemampuannya dan manajemen waktu belum efektif dan efisien sehingga rentan waktu terlalu lama dalam peningkatan hasil produksi. Nilai koefisien regresi sebesar -0,947 yang menunjukkan apabila jumlah tenaga kerja bertambah $1 \mathrm{HKO}$ akan menurunkan produksi sebesar $0,947 \mathrm{~kg}$ dengan asumsi variabel lain dianggap tetap, tetapi hal ini tidak akan berpengaruh secara nyata terhadap produksi kacang hijau.

d. Pengaruh tingkat pendidikan responden $\mathrm{X}_{4}$ ) terhadap produksi $(\mathrm{Y})$

Tingkat pendidikan tidak mempengaruhi produksi. Berdasarkan hasil analisis diketahui T-hitung $<$ T-tabel yaitu $(-0,100<1,680)$ yang berarti terima $\mathrm{H} 0$ dan tolak $\mathrm{H} 1$ dengan demikian untuk faktor tingkat pendidikan responden $\left(\mathrm{X}_{4}\right)$ tidak berpengaruh nyata terhadap produksi $(\mathrm{Y})$ pada taraf kepercayaan $5 \%$ Hal ini disebabkan oleh usahatani kacang hijau yang dijalankan tidak membutuhkan pengetahuan yang spesifik dalam pelaksanaannya. Usahatani kacang hijau telah turun temurun dijalankan oleh petani sehingga faktor pengalaman lebih nyata berpengaruh dibandingkan pendidikan, hal ini terbukti dengan pengujian terhadap variabel pengalaman berusahatani.

e. Pengaruh pengalaman responden $\left(\mathrm{X}_{5}\right)$ terhadap produksi $(\mathrm{Y})$

Berdasarkan hasil analisis diketahui T hitung $>$ T tabel yaitu $(4,614>1,680)$ yang berarti terima $\mathrm{H} 1$ dan tolak $\mathrm{H} 0$ dengan demikian untuk faktor pengalaman $\left(\mathrm{X}_{5}\right)$ berpengaruh nyata terhadap produksi $(\mathrm{Y})$ pada taraf kepercayaan $5 \%$, artinya jika pengalaman petani bertambah 1 tahun, maka akan meningkatkan produksi sebesar $1,243 \mathrm{~kg}$ dengan asumsi variabel lain dianggap tetap.

\section{Simpulan}

Sebesar 82,3\% produksi usahatani kacang hijau dipengaruhi oleh luas lahan, benih, curahan tenaga kerja, tingkat pendidikan, dan pengalaman secara bersama-sama sedangkan sisanya $17,7 \%$ adalah variabel lain. Secara parsial hanya variabel benih dan pengalaman petani yang berpengaruh terhadap produksi kacang hijau sedangkan luas lahan, curahan tenaga kerja dan tingkat pendidikan tidak berpengaruh nyata terhadap produksi usahatani kacang hijau.

\section{Pustaka}

Ating, S. \& Sambas, A.M. 2006. Aplikasi Statistika Dalam Penelitian. Bandung: Penerbit Pustaka Setia.

BPS Kab. Malaka 2014. Io Kufeu dalam Angka 2014. Betun: Badan Pusat Statistik Kabupaten Malaka.

BPS Kab. Malaka 2015. Io Kufeu dalam Angka 2015. Betun: Badan Pusat Statistik Kabupaten Malaka.
BPS Kab. Malaka 2016. Kecamatan Io Kufeu dalam Angka 2016. Betun: Badan Pusat Statistik Kabupaten Malaka.

Falo, M., Kune, S.J., Hutapea, A.N. \& Kapitan, O.B. 2016. Faktor-Faktor yang Mempengaruhi Produksi dan Strategi Pengembangan Usahatani Bawang Putih di Kecamatan Miomaffo Barat, Kabupaten Timor Tengah Utara. AGRIMOR, 1(04): 84-87.

Kurniawan, R. 2016. Analisis Regresi. Jakarta: Kencana.

Manehat, S.J., Taolin, R.I. \& Lelang, M.A. 2016. Pengaruh Jenis dan Dosis Pupuk Kandang Terhadap Pertumbuhan dan Hasil Kacang Hijau (Vigna radiata, L.). Savana Cendana, 1(01): 24-30.

Neonbeni, E.Y. \& Seran, A. 2017. Pengaruh Takaran Guano dan Konsentrasi Teh Kompos terhadap Pertumbuhan dan Hasil Kacang Hijau (Vigna radiata L.). Savana Cendana, 2(03): 42-45.

Rukmana, R. 1997. Kacang Hijau, Budi Daya \& Pascapanen. Jakarta: Kanisius. Santoso, S. 2008. Panduan Lengkap Menguasai Spss 16. Jakarta: Elex Media Komputindo.

Tetik, A.H. \& Fallo, Y.M. 2016. Analisis Pendapatan Usahatani Kacang Hijau di Kecamatan Wewiku Kabupaten Malaka. AGRIMOR, 1(03): 53-54. 